\title{
REPAYMENT AND REMISSION OF DUTY - AS AN ADMINISTRATIVE REMEDY- IN CUSTOMS TAX LAW: ISSUES ENCOUNTERED IN PRAXIS
}

\author{
Özgecan GÖK ${ }^{1}$
}

\begin{abstract}
It is possible to accept return or removal over calculated or collected customs duties through repayment and remission in accordance with the articles 211 and the rest article of the Customs Code. In this respect, repayment and remissionare both an administrative remedy and a key that ends disputes. Import-turn over Tax, Stamp Duty and TRT Banderol fees are taken into consideration, in terms of the scope of repayment and remission.

Repayment and remission remedies are problematic in practice due to the surveillance practice in imports. Declarations on surveillance reference price based upon unacceptable surveillance certificate and then apply the return and remedies on the basis of the calculation of the tax on the lower sales price cannot be considered as a remedy reason in view of European Union Law.

Remedies of repayment and remission may be made within three years from the date of the notification of the tax that has been accrued or paid. There are hesitations about how to calculate the three-year period for the compensatory customs duty under Article 194 of the Customs Code.

The decision given as a result of a remedy of repayment and remission is an administrative decision within the meaning of the Customs Code.

If the administration does not implement the decision to repayment within three months, it is required to pay the interest on tax refunds, which will be calculated on deferment interest from the expiry of this period. However, there is no need for a special arrangement for the interest payment of the administration; within the frame of the liability law, it is possible to eliminate to the taxpayers' loss arising from contra legem (unlawfully collected) taxes, by full remedy action.
\end{abstract}

Keywords: Repayment and Remission, interest on tax refunds, import turnover tax, banderol fee, stamp duty, surveillance measure on imports

JEL Code: K34, H20, B17.

\section{Introduction}

It is possible to have been notified and finally paid to anincomplete or over-calculated legal tax liability. In respect of customs duties, the recovery of this error enable within the framework of article 210-214 of the (Turkish) Customs Code.These regulations enable to correct the situations that are against the taxpayers. Import and rarely export taxes which should not be accrued or collected on the basis of the reasons regulatedin articles 211 to 214 of the Customs Code may be repaid or remit.

Excessive calculation or collection of the tax may arise at the customs administration's or the taxpayer's hand. The Customs Code is largely in line with the Community Customs Code, which

1 Res. Asst., Dokuz Eylül University, Division of Fiscal Law, ozgecangok@hotmail.com 
is currently not in force in the European Union. Existing recycling and lifting arrangements correspond to the regulations in Articles 235 to 242 of the Community Customs Code.The main reason of this regulation is the correction of improper taxation and ensuring an equal taxation and ensure this unity in the countries involved in the customs union.

The regulations related to repayment and removal in the fifth part of the ninth part of the customs duty of the Law are concretized by the regulations in articles 499 to 511 of the Customs Regulation.

The purpose of this Paper is to point out the repayment and remission as an administrative remedy and to indicate the problematic and controversial points. In this respect, issues such as scope, reasons of application, differences from other administrative remedies and results are examined.

\section{The Concept Of Repayment And Remission}

In the Article 210 of the Customs Code, the concepts of return and remission are defined as "the full or partical repayment of the paid customs duties and decided not to collect if it has not been paid yet paid." (Şenyüz vd., s. 348; Oktar, s. 275-277; R. Gültekin, s. 54 vd.; Nural, s. 617, 618).

The return as an administrative action corresponds to the concept of Restitution and remission corresponds to the concepts of deletion or remission of the tax duties in General Tax Law. (Saygılıoğlu \& Gerçek, s. 204; S. Kaya, s. 122, 123).

However, the return and remissionas an administrative remedy corresponds to error correction that regulated in Turkish Tax Code. Despite these two concepts serve to the same purpose the arrangement of the relevant laws are different from each other.

\section{Scope Of The Repayment And Remission}

\subsection{Overview}

The scope of repayment and remission is determined as customs duties and fines. Inclusion of fines in the scope of the repayment and remissiondoes not mean that fines will be repaidwhen customs duties are repaid.

But, if the misdemeanors are based on a separate legal basis, they wil not be tax based repaid or remit.For example, in accordance with Article 64 of the Customs Code, the cancellation of the declaration may result to the repayment or remission of the taxes; however, it does not bear legal consequences about fines.

The amount of customs duties which will not be subject to repayment and remission is equalized to the amount to deletion based on collection impossibility.

Taxes on imports or exports are largely seen in the list of Annex-1 to the Customs Settlement Regulation. Some of the taxes in this list are noteworthy in terms of repayment and remission. 


\subsection{In Terms of Value Added Tax in Imports}

According to the Article 48 of the Value Added Tax Code, the over Value Added Taxes which collected without considering tax exceptions should be repaid to the taxpayers who do not have the right to tax reduction. However, in customs administration applications, VAT on imports is considered as a customs duty. For this reason, the Customs Law should be applied in repayment and remission whether the taxpayer has the right of tax reduction or not (Yayla: 58-59).

Thus, the General Communiqué with the Serial No. 2 describes how VAT will be repay and remit to the taxpayers with or without the right of tax reduction.

\subsection{In Terms of TRT Banderol Fee}

According to TRT Income Code, TRT is also responsible for the remission of the Banderol fees that collected and transferred to TRT by Customs Authorities (Yayla: 59).

\subsection{In Terms of Antidumping Duty}

As an import duty, anti-dumping duty takes place in the scope of repayment and remission. The reference to the Customs Code in the Code of Prevention of Unfair Competition in Importation comes to the same conclusion.

Because of the necessity of enforce to the Agreement on the Implementation of Article VI of GATT 1994 in case of there is no provision in this Code, taxes that paid more than the dumping margin should also be repaid if they are requested with supporting evidence.

\section{Repayment And Remission Reasons}

\subsection{Overview}

Articles 211 to 214 of the Customs Code state the reasons for repayment and remissions as; non statutory tax collection and tax accrual, cancellation of the declaration, the case that the goods are contrary to the provisions of the contract or are faulty and the other reasons (Sariaslan: 80-81; Nural: 618-623; Avcl: 17-21).

Among these reasons, the reason that regulated in article 211 is really contradictive and featured. Therefore, only this reason will be examined in the study.

\subsection{Nonstatutory Tax Collection and Tax Accrual}

\subsubsection{Overview}

Non statutory tax collection and tax accrual are the most basic repayment and remission reason.

There are two points that need to be clarified. First, what the notion of nonstatutory tax collection or tax accrualare; the second is what the notion of intentional alteration is. 
In the decisions of the Council of State; it is seen that this notion is interpreted based on the decision of joint chambers in 1966. Accordingly, the customs duties that are requested repayment must be so clearly illegal that they do not need any examination, research and interpretation.

The decision of joint chambers in 1966 limits the reasons that regulated in Article 211 by introducing a clearly identifiable requirement. It is not possible to say that the decision of joint chambers is still has obligatory affect when we consider that it has been given when the Customs Code No. 1615 is in force.

The notion of nonstatutory tax collection or tax accrual should be thought, by taking into consideration to

* all the factors that give rise to the tax and the typicality in the daily life;

* and the special regulations at the level of the law for which the customs debt will be deemed unborn or taxes cannot be demanded.

Thus, in European Union Law it should be based on such a reason as;

- error in the discretion of the customs value; deducting the sale price which will be the basis of customs value by the parties,

- writing error or calculation error of the customspayer and as a result of it, use of the customs administration other methods of appreciation,

- not considered to tax benefits as preferential tariffs, exceptions and exemptions.

According to the Article 211, the application must not be based on an intentional alteration. This rule is expressed in different languages of the Community Customs Code by using different notions such as "deliberate action", "deceptive action". However, at the scope of the European Union practices, it is necessary to understand this notion as "the case that the intentional change of the data that plays a role in the emergence of the customs duties by related persons".

\subsubsection{Evaluation of Repayment and Remission in Customs Surveillance}

At this point, it is necessary to evaluate import surveillance, which is a trade policy measure. In practice, when importers can not able to get their surveillance document, they show the cost of the goods than the actual value by showing abroad expenses and increase the value of customs to the margin of audit. Thus, the goods release into free circulation.

However, after the persons have released the goods into free circulation, they demand partial repayment on the grounds that the value of the goods is lower. And also Council of State gives affirmative decisions about this topic. On the other hand, the customs administration evaluates this situation within the scope of the offense written in the sub-clause of Article 235, paragraph 1 of the Customs Code (Demir: 22).

When the misdemeanor is examined, it is thought that the situation this situation does not correspond to this definition of misdemeanor. Because with this regulation, the sanction of declaration of the unreal conditions is arranged. Moreover, two fold pecuniary punishment, loss of ownership and transferring property to the public would be unproportional sanction. 
In this case, the European Union practices should be taken as a basis; and when it comes to intentional declaration of the value of customs equal to the margin of audit, repayment requests must be rejected.

\section{Repayment And Remission Procedure}

\subsection{The Difference from the Other Administrative Remedies in the Customs Law}

The Customs Code is also an administrative procedure law. In addition to the application for repayment and remission, there are also other applications such request for a decision according to Article 6, appeal (objection) application according to Article 242 and the compromise application.

When a remedy for repayment and remission bases on an accrual decision, it would not easy to ascertain whether it is an objection application or a repayment and remission application. In this situation, a review should be made in order to provide legal protection and serve to resolve possible disputes quickly. For example, if there are arguments about the lawfulness of the decision to accrue in a repayment and remission application within the objection application period; this repayment and remission application should be considered as an appeal application.

Also, the reason given in article 211 is also a reason that can be considered within the scope of objection rewiev. And practice of the article 211 is more pratic and protective for taxpayer's rights. In this way, it is also easier to reach the judicial remedy.

\subsection{Application Form and Appeals Procedure}

In general, the repayment and remission procedure are regulated in Articles 502 and in the following articles of the Customs Code Implementing Regulation.

In terms of the procedure, the application deadlines are noteworthy. The Code clearly specifies the application deadlines for each reason except the cancellation of the declaration. It is possible to extend the application periods due to force majeure or unexpected circumstances.

It is considered that the application deadlines in article 211 can be taken into consideration in terms of cancellation of the declaration (Dş. 7. D. 4.5.2016 tarih ve E. 2013/4415; K. 2016/4282).

It is also unclear that when will be application period begin about compensatory tax under the Article 194 of the Customs Code. There is a need for a definite rule about the notification date. (Keleş: 55- 56).

\subsection{Results of the Application and the Problem about Interest to be paid to the Taxpayer}

The result of the removal and remission application is "a decision" in the meaning of the Customs Law for this reason it is necessary to exhaust this remedy before resort to jurisdiction. According to article 216 of the Customs Code, the decision must be enforced in three months after the decision of administration, otherwise the administration will have to pay deferment interest. Despite the decision of the Constitutional Court about article 216 that is about nonpayment of the interest by administration, this regulation still means "the administration will not pay a deferment interest if the decision is enforced in three months". But according to our opinion, despite absence of a positive legal regulation, it is possible to compensate taxpayer's loss through full remedy action (Karakoç, Faiz-I: 34; Candan: 164). 
According to article 192 of Customs Code, there is a joint liability between the persons who have liability to the pay same customs duty. Despite absence of a positive legal regulation, even if only one taxpayer applies remedy and remission, the decision about the apply will be affect all consecutive taxpayers. But if the reason of the removal and remission related to the applicant's personality, the decision will be effective for only applicant own (Witte/Alexander: 1760).

\section{Conclusions}

Repayment and remission are administrative remedy that serves to remedy disputes at the administrative degree.

The customs duties and penalties are evaluated independently according to their legal basis.

Value Added Taxes received from the import, the TRT Banderol fee and the anti-dumping duty should be evaluated by taking into consideration to their characteristic speciality regarding each remedy.

In the surveillance practice implemented as a trade policy measure in imports, when it comes to intentional declaration of the value of customs equal to the margin of audit, repaymentand remission requests must be rejected.

There is a need for a definite and comprehensible regulation about the notification date of cancellation of the declaration and compensatory tax that regulated in Article 194 of the Customs Code.

The application for repayment and remission is an decision request within the meaning of Article 6 of the Customs Law. Therefore, the decision given as a result of the application subjects to the objection procedure that regulated in Article 242 of the Customs Code.

Against to notification of the accrual decision, applying for objection (appeal) instead of applying for the repayment and remissionis in favor of the taxpayer.

Despite absence of a positive legal regulation and the result of the article 216 of the Customs Code that means "the administration will not pay a deferment interest if the decision is enforced in three months", it is possible to compensate taxpayer's loss arising from unlawfull taxation through full remedy action.

\section{References}

\section{Journals/Periodicals;}

Avcı, I.E. (2011). "Gümrük Vergilerinin Geri Verilmesi ve Kaldırılması”, Gümrükte Uzman Görüş, Y. 9, S. 31, Ekim-Aralık 2011, ss. 16-22.

Candan, T. (2013). "Hukuka Aykırı Olarak Tahsil Edilen Vergilerin Geri Verilmesinde Faiz", Mali Çözüm Dergisi, S. 118, Temmuz-Ağustos 2013, ss. 161-186.

Demir, N. (2017). “ithalatta Gözetim Uygulaması (Sorunlar ve Çözüm Önerileri)”, Gümrük ve Ticaret Dünyası, Y. 2017/4, S. 95, ss. 19-23. 
Karakoç, Y. (2001). “Vergi İdaresince İade Edilmesi Gereken Yükümlü Alacaklarına Faiz Uygulaması (I)", Mükellefin Dergisi, S. 107, Kasım 2001, ss. 33-44. (Faiz-I)

Karakoç, Y. (2001). "Vergi İdaresince İade Edilmesi Gereken Yükümlü Alacaklarına Faiz Uygulaması (II)", Mükellefin Dergisi, S. 108, Aralık 2001, ss. 114-125. (Faiz-II)

Kaya, S. (2011). “Gümrükte Vergi Planlaması”, Mali Çözüm Dergisi, S. 105, Mayıs-Haziran 2011, ss. $109-126$.

Keleş, Ş. (2017). "Telafi Edici Verginin Geri Verilmesinde Yaşanan Tereddütler", Gümrük ve Ticaret Dünyası, S. 95, 2017/4, ss. 55, 56.

Şenol, C. (2012). "Gümrük Vergileri ve Para Cezalarında Geri Verme ve Kaldırma”, Gümrük Dünyası, Y. 2012/3, S. 74, ss. 27-36.

Yayla, S. (2018). "Gümrük Vergi ve Para Cezalarının Geri Verilmesi ve Kaldırılması”, Gümrük ve Ticaret Dünyası, Y. 2018/1, S. 96, ss. 23-27.

\section{Books;}

Aydın, S., Topuz, N., Beyribey, K. (2000). Gerekçeli, Notlu, Içtihatlı, 4458 Sayılı Gümrük Kanunu ve ilgili Mevzuat, Ankara, Seçkin Yayıncılık.

Beck, M., Bendix, K., Huchatz, W. (2012). Lehrbuch Abgabenrecht für Zölle und Verbrauchsteuern, Herne, nwb Ausbildung.

Çelik, B. (1999). Dış Ticaretten Alınan Vergilerden Gümrük Vergisi Hukuku, Ankara, İmaj Yayıncılık.

Fuchs, K. (2006). Bundesabgabenordnung und EG-Zollrecht, Wien, Linde Verlag.

Gök, Ö. (2019). Gümrük Vergisinden Kaynaklanan Uyuşmazlıklar, Ankara, Yetkin Yayınları.

Lux, M. (2009). Das Zollrecht der EG (Handbuch für Praktiker mit Musterfällen und Praxistipps), 3. Auflage, Köln, Bundesanzeiger Verlag.

Nural, A. (2015). 4458 Sayılı Gümrük Kanunu -Açıklamalı-, Ankara, Yeni Gümrük ve Ticaret Müfettişleri Derneği İktisadi İşletmesi Yayın No: 2 (33).

Sarıaslan, O. (2014). Vergi Uyuşmazlıklarına ilişskin Davalarda Ilk Inceleme, Ankara, Türkiye Adalet Akademisi.

Saygıııŏlu, N., Gerçek, A. (2007). Dış Ticaret ve Gümrük Kurallar, İşlemler ve Vergileme, Ankara, Yaklaşım Yayıncılık.

Şenyüz, D., Yüce, M., Gerçek, A. (2018). Türk Vergi Sistemi, 15. Baskı, (Ekin Yayınevi), Bursa.

Summersberger, W. (2002). Grundzüge des Zollrechts, Wien, Lexis Nexis.

Tschiderer, S. (2011). EU-Zollrecht, 2. aktualisierte Auflage, Wien, Lexis Nexis.

Witte, P. (2013). Zollkodex Kommentar, 6. neubearbeitete Auflage, München, Verlag C.H. Beck.

Thesis:

Gültekin, R. (2008). Türkiye'de Dış Ticaretten Alınan Vergiler ve Eş Mali Yükümlülükler, Trakya Üniversitesi Sosyal Bilimler Enstitüsü Maliye Anabilim Dalı, (Yayımlanmamış Yüksek Lisans Tezi), Edirne. 